\title{
Infantile Cortical Hyperostosis
}

Nika Morgan, Sara Bertok,

Damjana Ključevšek, Karin Schara, Jana Lozar Krivec

\section{Izvleček}

Infantilna kortikalna hiperostoza ali Caffeyjeva bolezen je redka dedna bolezen, ki je posledica mutacije $v$ genu za kolagen tipa 1. Mehanizem nastanka bolezni še ni povsem pojasnjen, patofiziološka osnova bolezni in posledica mutacije pa je vnetje v periostu kosti. Klinično se bolezen izrazi $z$ asimetrično zadebelitvijo kostnine $v$ prvih mesecih življenja, najpogosteje v področju spodnje čeljusti, ključnice, lopatice, reber in dolgih kosti udov. Prizadetost kosti pogosto spremljajo nespecifični sistemski znaki. Pri postavitvi diagnoze je v veliko pomoč rentgensko slikanje, ki prikaže hiperostozo kostnine. Diagnozo potrdimo z genetsko analizo. Zdravimo simptomatsko. Pri napovedi izida bolezni igra pomembno vlogo način dedovanja. Prenatalna oblika bolezni, ki se deduje avtosomno recesivno, ima slabo napoved izida, infantilna oblika bolezni, ki se deduje avtosomno dominantno, pa navadno brez posledic do drugega leta starosti spontano izzveni. V prispevku predstavljamo klinični primer novorojenčka z infantilno obliko Caffeyjeve bolezni, pri kateri smo dokazali mutacijo gena COL1A1.

Ključne besede: Caffeyjeva bolezen, kolagen tipa 1, mutacija gena COL1A1, novorojenček, bolezen kosti, kortikalna hiperostoza.

\begin{abstract}
Infantile cortical hyperostosis or Caffey disease is a rare genetic disorder caused by a mutation in the collagen 1 gene. The mechanism of the disease has not yet been fully elucidated, but the most important factor in the pathogenesis and the consequence of the mutation is periosteal inflammation. The disease becomes clinically evident during the first months of life with asymmetrical bone thickening, most commonly in the mandible, clavicle, scapula, ribs, and long bones. Non-specific systemic inflammatory symptoms can also be present. X-ray imaging with demonstration of bone hyperostosis is essential for the diagnosis, which is confirmed by genetic testing. Treatment is symptomatic. The prognosis of the disease depends on the mode of inheritance. The autosomal recessive form, known as the prenatal form, has a poor prognosis. The autosomal dominant form or infantile Caffey disease usually resolves spontaneously without consequences before the age of two years. We present a case of a neonate with Caffey disease with proven COL1A1 gene mutation.
\end{abstract}

Key words: Caffey disease, collagen type 1, COL1A1 gene mutation, newborn, bone disease, cortical hyperostosis. 


\section{Uvod}

Prirojene kostne nepravilnosti uvrščamo med redke vzroke spremenjene kostnine pri novorojenčku (1). Spremenjena kostnina je veliko pogosteje posledica porodnih poškodb in okužb, medtem ko so prirojeni presnovni vzroki, kongenitalni sifilis in bolezen krhkih kosti (osteogenesis imperfecta) redkejši vzrok sprememb kostnine $v$ novorojenčkovem obdobju $(1,2)$. V prispevku predstavljamo novorojenčka z infantilno kongenitalno hiperostozo kosti ali Caffeyjevo boleznijo (CB), ki jo uvrščamo med redke prirojene bolezni kosti (1). Je posledica mutacije $v$ genu za kolagen tipa 1, ki se lahko deduje ali pojavi sporadično (3). Glede na način dedovanja in klinični potek razlikujemo dve obliki bolezni: prenatalno, ki se deduje avtosomno recesivno, in infantilno, za katero je značilen avtosomno dominanten način dedovanja. Pri prenatalni CB spremembe kosti vidimo že pri plodu, bolezen pa ima zaradi številnih zapletov po rojstvu izredno slabo prognozo (1). Infantilna oblika bolezni kljub dramatični klinični sliki v začetku poteka relativno stabilno in ima dobro prognozo $(1,2)$. Popolna remisija navadno nastopi do drugega leta starosti in običajno, zaradi remodelacije kostnine, ne pušča trajnih posledic (4).

\section{Prikaz primera}

Deklica se je rodila po drugi nosečnosti 38. letne zdrave matere. Med nosečnostjo je imela mati sladkorno bolezen, zato se je držala diete. Sicer je nosečnost potekala brez zapletov, presejalno testiranje na okužbo s sifilisom, hepatitisom B in toksoplazmo pa je bilo negativno. Družinska anamneza za bolezni kosti je bila negativna.

Porod je bil atravmatski, spontan in s popadki, nato pa so ga spodbudili z oksitocinom. Vstava je bila zatilna. Zaradi pozitivnega brisa na bakterijo Streptococcus agalactiae je mama med porodom prejela penicilin. Po

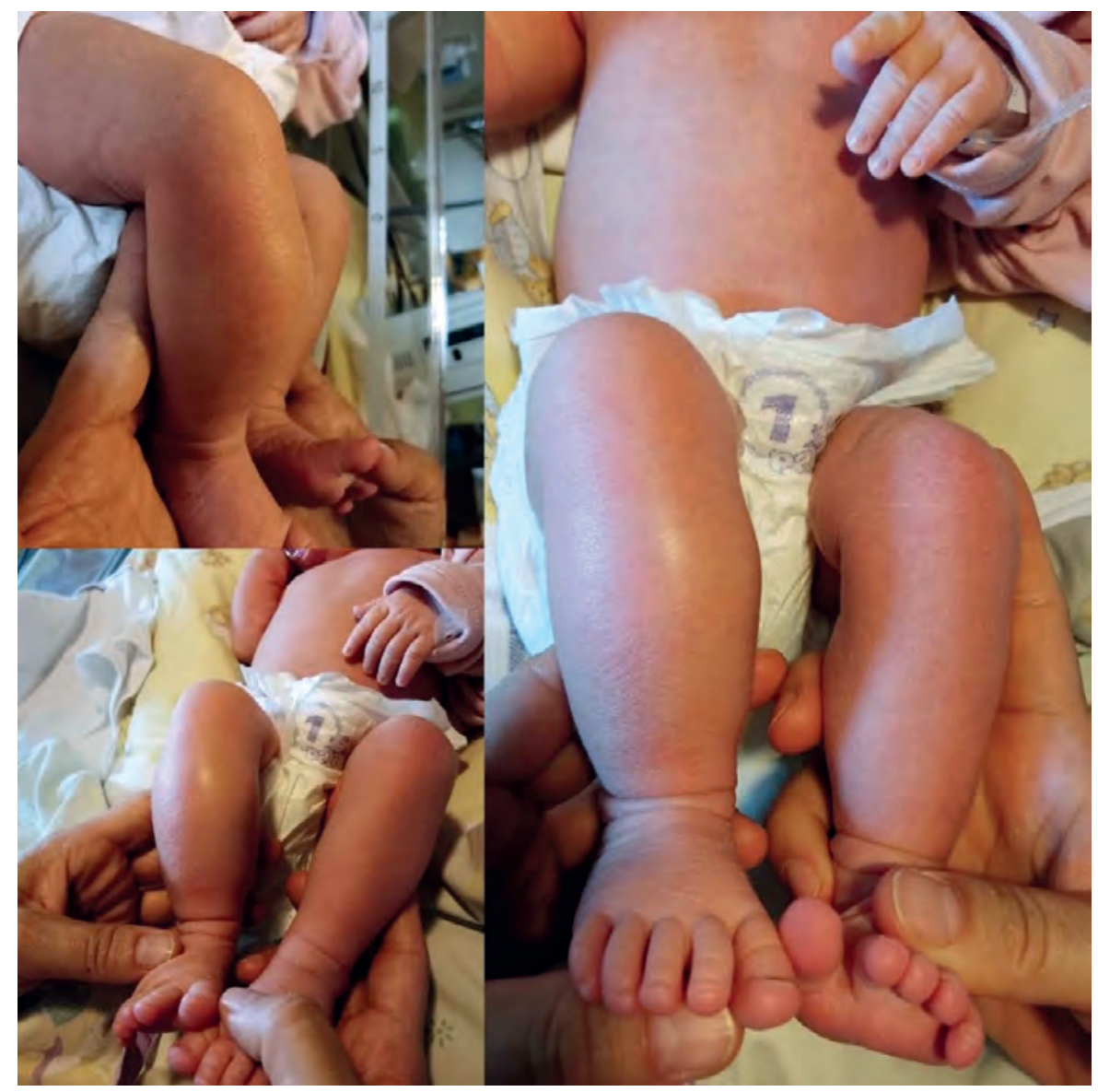

SLIKA 1. KLINIČNA SLIKA. ANTEROMEDIALNO IZBOČENJE OBEH GOLENI.

FIGURE 1. CLINICAL PRESENTATION. ANTEROMEDIAL TUMEFACTION OF BOTH TIBIAS.

dopolnjenem 39. tednu nosečnosti se je rodila deklica s primernimi porodnimi merami, tj. telesno težo $3780 \mathrm{~g}$, dolžino $51 \mathrm{~cm}$ in obsegom glave 35 $\mathrm{cm}$. Prvi oceni po Apgarjevi sta bili 9 in 10 . Ob prvem kliničnem pregledu so opažali izbočenje in zadebelitev obeh goleni in koželjnice leve roke. Zaradi nadaljnjega diagnosticiranja prirojenih nepravilnosti kosti je bila v starosti šest dni premeščena na Klinični oddelek za neonatologijo Pediatrične klinike v Ljubljani.

Ob kliničnem pregledu smo ugotavljali zadebelitev in deformacijo anteromedialno $v$ celotnem poteku obeh goleni, ki je bila bolj izražena desno. Prisotna je bila razlika v dolžini spodnjih udov; desni spodnji ud je bil za $1 \mathrm{~cm}$ daljši (Slika 1). Tipna je bila tudi manjša izboklina na levem zgornjem udu medialno, v poteku koželjnice. Omenjene spremembe na otip niso bile boleče, koža nad izbočeno in zadebeljeno kostjo pa je bila nespremenjena. $V$ področju sklepov nismo opažali posebnosti. Prisotni so bili diskretni dismorfni znaki obraza, hipertelorizem in epikantus.

Deklica je bila na oddelku vseskozi neprizadeta in afebrilna ter brez bolečin in razdražljivosti. Sprva je imela manjše težave s hranjenjem, nato pa je pričela ustrezno pridobivati telesno maso. $V$ laboratorijskih izvidih so bile vrednosti vnetnih kazalnikov negativne, vrednosti elektrolitov, in dušičnih retentov ter plinska 


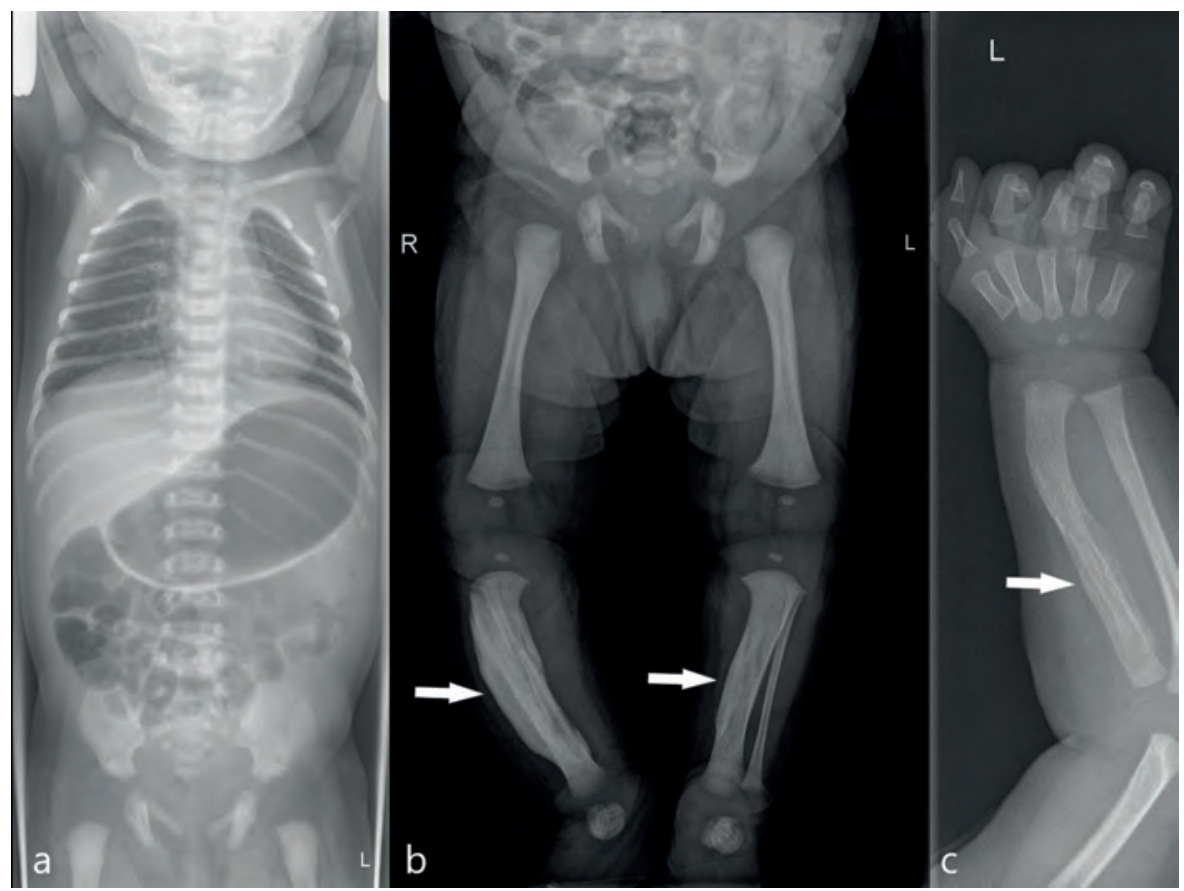

SLIKA 2. SKELETNI RENTGENOGRAMI 5-DNEVNE DEKLICE S CAFFEYJEVO BOLEZNIJO: A) PRSNI KOŠ IN CELOTNA HRBTENICA LEŽE V ANTEROPOSTERIORNI PROJEKCIJI STA MORFOLOŠKO IN STRUKTURNO V MEJAH NORMALNEGA; B) MEDENICA IN SPODNJA UDA Z IZRAZITO PREKOMERNO TVORBO KOSTI (HIPEROSTOZO) DESNE GOLENI IN NEKOLIKO MANJ IZRAZITO LEVE GOLENI, TJ. TIPIČNE SPREMEMBE ZA CAFFEYJEVO BOLEZEN; C) LEVI ZGORNJI UD Z ZMERNO HIPEROSTOZO KOŽELJNICE.

FIGURE 2. SKELETAL X-RAYS IN A 5-DAY-OLD GIRL WITH CAFFEY DISEASE: A) CHEST AND THE WHOLE SPINE IN THE SUPINE ANTEROPOSTERIOR POSITION ARE MORPHOLOGICALLY AND STRUCTURALLY NORMAL, B) PELVIS AND LOWER LIMBS WITH EXCESSIVE OSSIFICATION, HYPEROSTOSIS, OF BOTH TIBIAS ESPECIALLY ON THE RIGHT - TYPICAL CHANGES OF CAFFEY DISEASE, C) LEFT UPPER ARM WITH MODERATE HYPEROSTOSIS OF THE RADIUS.

analiza krvi pa normalne. Vrednost vitamina $D$ je bila pod optimalno ravnijo (49 $\mathrm{nmol} / \mathrm{l})$, kostna alkalna fosfataza pa povišana $(132 \mu \mathrm{g} / \mathrm{l}$, referenčne vrednosti pri deklicah, mlajših od enega leta: $39,5-89 \mu \mathrm{g} / \mathrm{l}(5))$. Vrednost parathormona je bila normalna (27 ng/l). Na rentgenskem posnetku spodnjih udov je bila vidna izrazita hiperostoza v celotnem poteku desne golenice, manj izrazito tudi leve (Slika 2). Hiperostoza je bila prisotna tudi v področju leve koželjnice, medtem ko $v$ predelu reber, ključnice, nadlahtnic in stegnenic ni bilo posebnosti (Slika 2). Za izključitev drugih anomalij smo opravili ultrazvočni pregled glave, srca in trebuha, ki so bili v mejah normalnih vrednosti.
Na podlagi rentgenskih sprememb kosti in otrokove starosti je bila CB v didferencialni diagnozi prva možna bolezen kosti. Radiološko podobni CB sta primarna hipertrofična osteoartropatija in Camurati-Engelmannov sindrom, ki pa se običajno ne izrazita v zgodnjem otroštvu $(6,7)$. Manj verjetna diferencialnodiagnostična možnost je huda oblika osteogenesis imperfecta (tip III), pri kateri nastopijo zlomi kosti že pred rojstvom ali ob najmanjši manipulaciji, pogosto pa so poleg zlomov in osteopenije vidne tudi deformacije $v$ predelu dolgih kosti po predhodnih zlomih $(8,9)$. Z diagnozo CB je soglašal tudi konzultant Evropske referenčne mreže za redke bolezni kosti (ERN BOND). $Z$ genetsko analizo po metodi direktnega sekvenciranja za tarčno mutacijo smo dokazali mutacijo $\mathrm{v}$ genu COL1A1 (c.3040C>T; p.Arg1014Cys), ki pri bolnici potrjuje CB. Enako mutacijo smo ugotovili pri dekličinem očetu, ki nima znakov bolezni oziroma se ne spominja, da bi jih imel.

Deklico smo spremljali ambulantno. Postopno je prišlo do kliničnega in radiološkega izboljšanja stanja.

\section{Razpravljanje}

Infantilna kortikalna hiperostoza ali Caffeyjeva bolezen je bolezensko stanje, za katerega je značilno povečano subperiostalno nastajanje kostnine (hiperostoza) na eni ali več kosteh, ki se navadno pojavi v prvih mesecih življenja (3). Bolezen je leta 1930 prvič opisal nemški pediater Roske, natančneje pa sta jo opredelila Silverman in Caffey leta $1945(1,2,10)$.

CB je posledica mutacije gena COL1A1, ki kodira a-verigo kolagena tipa I (1-3). Gen se nahaja na dolgem kraku kromosoma 17, regija 17q21.33 (11). Najbolj znana vzročna mutacija je na 41. eksonu gena, ki privede do zamenjave nukleotidnega zaporedja na mestu 3040, kjer se citozin zamenja s timinom (c.3040C>T) (3). Posledica zamenjave je sprememba aminokislinskega zaporedja v kolagenski verigi, substitucija arginina za cistein (Arg836Cys) (3). Mutacija po še ne povsem jasnem mehanizmu povzroči vnetje periosta ter posledični proliferacijo fibroblastov in zadebelitev kostnine $(1,2,4)$.

Domnevajo, da lahko substitucija arginina s cisteinom $v$ kolagenski verigi povzroči nepravilnosti pri tvorbi disulfidnih vezi (3). Spremenjene verige naj bi bile sposobne tvorbe številčnejših vezi, kar velja tudi za povezave $z$ drugimi beljakovinami in peptidi v zunajceličnem matriksu (3). Poleg tega naj bi imela spremenjena veriga veliko afiniteto za interlevkin 2 in amiloidni prekurzorski protein, s čimer bi lahko pojasnili nastanek vnetja v periostu (3). Druga možna hipoteza nastanka 
bolezni je vnetni odgovor na še neznano virusno okužbo ali imunski sprožilec, saj so sporadični primeri kortikalne hiperostoze znani tudi ob odsotnosti genetskega dejavnika (2). Pomembno vlogo pri nastanku hiperostoze bi lahko imeli prostaglandini, saj so hiperostotske spremembe radiološko opažali pri kar $62 \%$ otrok, ki so zdravljenje s prostaglandini zaradi srčne napake, odvisne od Bottalovega voda, potrebovali dlje od 60 dni (12).

CB se najpogosteje deduje avtosomno dominantno in z nepopolno penetran$c o, v$ redkejših primerih pa se lahko deduje na avtosomno recesivni način. Večina mutacij nastane sporadično (1, $3,4)$.

Avtosomno recesivna oblika je povezana z redkejšo in hujšo obliko bolezni, pri kateri so spremembe kostnine vidne že prenatalno $(1,13)$. Zanjo je značilna obsežna hiperostoza kosti z angulacijo in prikrajšavo dolgih kosti, polihidramnij ter visoka smrtnost intrauterino ali takoj po rojstvu zaradi hidropsa ploda, nedonošenosti in slabega razvoja pljuč $(1,13)$.

Avtosomno dominanten način dedovanja je navadno povezan $z$ bolj milo, infantilno obliko bolezni (1). Gre za redko bolezen, pri kateri veliko primerov zaradi blage klinične slike ostane neprepoznanih, zato natančne pojavnosti ne poznamo $(1,14)$. Mutacija je lahko dedna ali nastane na novo (1, $3,15)$. Na pojavnost bolezni ne vplivata spol in rasa (14). Infantilna $C B$ se navadno manifestira $v$ prvih šestih mesecih starosti, v literaturi pa povprečno starost ob pojavu kliničnih znakov ocenjujejo na 9 tednov $(1,4$, $8,16)$. Najpogosteje prizadete kosti so spodnja čeljust (79-90\%), ključnica, lopatica, rebra in dolge kosti udov (1, $4,16)$. Pri sporadični obliki bolezni so spremembe kostnine največkrat vidne v področju spodnje čeljusti, ključnice, reber in podlahtnice, medtem ko je familiarna oblika bolezni pogosteje povezana s prizadetostjo golenice, kar dobro korelira tudi z našim kliničnim primerom (15). Prizadetost kosti je običajno asimetrična in večžariščna (1). Pogosto so kostnim spremembam pridruženi nespecifični sistemski bolezenski znaki, kot so povišana telesna temperatura, razdražljivost, slabše hranjenje ter otekline mehkih tkiv in bolečina $(1,4,10,16)$. $V$ našem primeru drugih znakov sistemske prizadetosti, razen začetnih težav s hranjenjem, nismo opažali.

Pomembno vlogo pri postavitvi diagnoze ima družinska anamneza $(1,2)$. Bolezen lahko poteka zelo subtilno ali pa so osebe $z$ mutacijo lahko celo brez simptomov (3). Tudi v našem kliničnem primeru, ko ima dekličin oče enako genetsko spremembo kot hčerka, v anamnezi pa ni podatka, da bi imel $v$ zgodnjem otroštvu spremembe na kosteh, bi lahko šlo za brezsimptomno bolezen ali manjše, subklinične spremembe na kosteh, ki so s časom, kot je značilno za infantilno obliko, izzvenele in jih zato niso opazili.

Laboratorijski izvidi so nespecifični (1). Pogosto opažamo zvišane vrednosti sedimentacije in C-reaktivnega proteina, levkocitozo, trombocitozo ter zvišane vrednosti alkalne fosfataze in imunoglobulinov, kar dodatno nakazuje na pomembno vlogo vnetnega dogajanja v patogenezi bolezni (4).

$\checkmark$ slikovnem diagnosticiranju je nepogrešljivo rentgensko slikanje prizadetega dela telesa $v$ dveh projekcijah, $\mathrm{ki}$ nazorno pokaže hiperostozo kostnine $(1,4,16)$. Ob prizadetosti dolgih kosti se spremembe navadno pojavljajo $v$ področju diafize, medtem ko sta epifiza in metafiza običajno neprizadeti $(4,16)$. Diagnozo dokončno potrdimo $z$ genetsko analizo in dokazom mutacije v genu $\operatorname{COL1A1}(1,3)$.

Zdravljenje je simptomatsko (1). V primeru bolečin je pomembno zdravljenje $z$ analgetiki (14). Če so zagoni bolezni pogosti in jih spremljajo vročina, huda razdražljivost, slabo pridobivanje telesne mase ali drugi simptomi, ki ovirajo normalno rast in razvoj otroka, $v$ literaturi kot uspešno navajajo zdravljenje z nesteroidnimi antirevmatiki (ibuprufen ali naproksen) (15), kortikosteroidi $(3,8)$ ali indometacinom (17). $V$ našem primeru deklica ni imela bolečin in pridruženih sistemskih znakov bolez$\mathrm{ni}$, zato zdravljenja ni potrebovala.

Napoved izida bolezni je pri infantilni obliki CB praviloma dobra. $V$ fazi remodelacije kosti se odvečno kostno tkivo reabsorbira in preoblikuje na način, ki dolgoročno ne vpliva na spremembo $v$ zgradbi kosti $(4,16)$. $V$ primeru prizadetosti dolgih kosti udov je lahko potek remodelacije nekoliko daljši, redko opisujejo celo spoje sosednjih kosti ali asimetrije obraza $(8,16)$. Bolezen lahko poteka v obliki zagonov in remisij v obdobju od 2-3 tednov do nekaj mesecev (7). Dokončna remisija običajno nastopi pri starosti približno dve leti (1), čeprav v literaturi opisujejo posamezne primere ponovnega zagona bolezni v času pubertete (16).

\section{Zaključek}

Caffeyjeva bolezen je redka dedna bolezen in je posledica mutacije $v$ genu COL1A1, ki kodira kolagen tipa 1. Kljub številnim raziskavam mehanizem nastanka vnetja periostalno, $\mathrm{ki}$ ima ključno vlogo $v$ patogenezi bolezni in nastanku hiperostoze, še ni povsem pojasnjen. Bolezen lahko poteka v obliki zagonov. Klinično opažamo asimetrično zadebelitev kosti, ki z remodelacijo kostnine postopno izgine. Dokončna remisija bolezni večinoma nastopi do drugega leta starosti. Bolezen ne zapušča dolgotrajnih posledic na rast in razvoj otroka. 


\section{Literatura}

1. Prior AR, Moldovan O, Azevedo A, Moniz C. Caffey disease in neonatal period: the importance of the family! BMJ Case Rep 2012; 2012 : bcr2012006996.

2. Pinheiro PC, Aymore IL, Amoedo AR, Hemais PM. Infantile Cortical Hyperostosis: Report of a case with Observations on Clinical Manifestations, Radiology, and Pathology with a Late Follow-Up of Eight Years. Case Rep Pediatr 2016; 2073854.

3. Gensure RC, Mäktie O, Barclay C, Chan C, DePalma SR, Bastepe M, et al. A novel COL1A1 mutation in infantile cortical hyperostosis (Caffey disease) expands the spectrum of collagen-related disorders. J Clin Invest 2005; 115 : 1250-1257.

4. Nistala H, Mäktie O, Jüppner H. Caffey disease: New perspectives on old questions. Bone 2014; 60: 246-51.

5. Fischer DC, Mischek A, Wolf S, Rahn A, Salweski B, Kundt $G$, et al. Paediatric reference values for the C-terminal fragment of fibroblast-growth factor-23, sclerostin, bone-specific alkaline phosphatase and isoform $5 \mathrm{~b}$ of tartrate-resistant acid phosphatase. Ann Clin Biochem 2012;4 9(Pt 6): 546-53.

6. Sharma D, Pawar SR, Bharathi S, Shastri S. Primary Hypertrophic Osteoarthropathy (Touraine-Solente-Gole Syndrome) in Newborn: A Rare Orthopedic Condition Seen in Newborn. Journal of Clinical Neonatology 2016; 5: 51-54.

7. Van Hul W, Boudin E, Vanhoenacker FM, Mortier G. Camurati-Engelmann Disease. Calcif Tissue Int. 2019 May;104(5):554-560.8. Spranger JW, Lausch E. Hyperostosis in siblings. SAMJ 2016; 106 (6): S98-99.

8. Hall C. Caffey disease. Orphanet encyclopaedia. 2005. Dosegljivo na: http://www.orpha.net/ data/patho/GB/uk-caffey05.pdf.

9. Basel D, Steiner RD. Osteogenesis imperfecta: recent findings shed new light on this once well-understood condition. Genetics in medicine, 2009. 11 (6): 375-385.

10. Spranger JW, Lausch E. Hyperostosis in siblings. SAMJ. 2016. 106 (6): S98-99.

11. Gilbert F. Disease genes and chromosomes: disease maps of the human genome. Chromosome 17. Genet Test 1998; 2(4): 357-81.

12. Woo K, Emery J, Peabody J. Cortical hyperostosis: a complication of prolonged prostaglandin infusion in infants awaiting cardiac transplantation. Pediatrics 1994; 93: 417-420.

13. Kamoun-Goldrat A, Martinovic J, Saada J, Sonigo-Cohen P, Razavi F, Munnich A, et al. Prenatal cortical hyperostosis with COL1A1 gene mutation. Am J Med Genet A 2008; 146A(14): 1820-4.

14. Kutty N, Thomas D, George L, John TB Caffey disease or infantile cortical hyperostosis: a case report. Oman Med J 2010; 25(2): 134-6.

15. Borochowitz Z, Gozal D, Misselevitch I, Aunallah J, Boss JH. Familial Caffey's disease and late recurrence in a child. Clin Genet 1991; 40(4): 329-35.

16. Glorieux FH. Caffey disease: an unlikely collagenopathy. J Clin Invest 2005; 115(5): 1142-4.

17. Couper RT, McPhee A, Morris L. Indomethacin treatment of infantile cortical periostosis in twins. J Paediatr Child Health 2001; 37(3): 305-8.
Nika Morgan, dr. med.

Oddelek za pediatrijo, Splošna bolnišnica Izola, Izola, Slovenija

as. dr. Sara Bertok, dr. med.

Klinični oddelek za endokrinologijo, diabetes in bolezni presnove, Pediatrična klinika, Univerzitetni klinični center Ljubljana, Ljubljana, Slovenija

izr. prof. Damjana Ključevšek, dr. med.

Služba za radiologijo, Pediatrična klinika, Univerzitetni klinični center Ljubljana, Ljubljana, Slovenija

mag. Karin Schara, dr. med. Oddelek otroške ortopedije, Ortopedska klinika, Univerzitetni klinični center Ljubljana, Ljubljana, Slovenija

dr. Jana Lozar Krivec, dr. med. (kontaktna oseba / contact person) Klinični oddelek za neonatologijo, Pediatrična klinika, Univerzitetni klinični center Ljubljana, Ljubljana, Slovenija e-naslov: jana.lozar@guest.arnes.si

prispelo / received: 8. 12. 2020

sprejeto / accepted: 9. 3. 2021

Morgan N, Ključevšek N, et.al. Infantilna kortikalna hiperostoza. Slov Pediatr 2021; 28(2): 103-107. https://doi.org/10.38031/ slovpediatr-2021-2-06. 